\title{
Insecticidal Activities of the Essential Oil of Aegle marmelos (Linnaeus, 1800) against Aedes aegypti (Linnaeus, 1762) and Culex quinquefasciatus (Say, 1823)
}

\author{
Riju Sarma, Sudarshana Mahanta, Bulbuli Khanikor"
}

Department of Zoology, Gauhati University, India

Copyright $\mathrm{C} 2017$ by authors, all rights reserved. Authors agree that this article remains permanently open access under the terms of the Creative Commons Attribution License 4.0 International License

\begin{abstract}
Essential oil from the leaves of Aegle marmelos was investigated for their larvicidal, ovicidal, adulticidal and repellent properties against Aedes aegypti and Culex quinquefasciatus. Essential oil was extracted from the fresh leaves by hydro distillation method. Different concentrations of the oil were applied against different developmental stages of both the mosquito species. The result of different bioassay showed various responses between the species. The essential oil showed higher efficacy as larvicidal and adulticidal agent against $C x$. quinquefasciatus (LC50=121.88ppm against larva and $121.50 \mathrm{ppm}$ against adult at 72 hour exposure) while as ovicidal and repellent agent, the essential oil showed higher efficacy against Ae. aegypti with LC50 value $278.82 \mathrm{ppm}$ at 72 hour and 1 hour of protection time respectively. Therefore, it can be inferred that this essential oil is a potential one which could further be used as mosquitocidal agent against both the mosquito species. The GC-MS analysis revealed the presence of $\beta$ - terpinyl acetate, 5- isopropenyl-2methyl-7-oxabicyclo (4.1.0) hepten-2-ol and 2,3-pinanediol as major probable constituents of the oil which might play major role against insecticidal activities of the plant oil.
\end{abstract}

Keywords Aegle marmelos, Essential Oil, Aedes aegypti, Culex quinquefasciatus, Larvicidal, Adulticidal, Ovicidal, Repellent

\section{Introduction}

Mosquitoes are medically important insects and are considered as major public health pests as they transmit many dreadful diseases to humans and other warm blooded vertebrates [1]. Aedes aegypti and Culex quinquefasciatus are two important mosquito species under Culicidae family which transmit different diseases like dengue, yellow fever, chikungunya, Japanese encephalitis, and filariasis etc. Aedes aegypti, a mosquito with distinct white bands in legs and abdomen is the common vector of dengue in tropical and subtropical countries [2]. Dengue fever has become an important problem related to public health as the number of its occurrence increases day by day, especially with more drastic forms of this disease such as dengue hemorrhagic fever and dengue shock syndrome along with the involvement of central nervous system [3, 4]. Again, Culex quinquefasciatus, a brown-coloured medium-sized mosquito has been established as the vector of Wuchereria bancrofti (Cobbold, 1877), avian malaria and arbo viruses including St. Louis encephalitis virus, western equine encephalitis virus, West Nile virus, various protozoan etc. About 1.10 billion people are threatened by this disease in 58 countries worldwide. In India, 19 million people suffer from filarial disease manifestations.

In present time, mosquito control programme faces a serious problem as mosquitoes are developing resistance against different chemical insecticides. Not only the rapid resistance development, these insecticides also possess various side effects on non-target organisms. Therefore, the search for alternative control measures other than synthetic insecticides that pose no or minimal risk to human health and the environment is extensively going on worldwide [5]. From these points, plant based products mainly the extracts and essential oils can be safely included in the integrated mosquito control programme as alternative to chemical insecticide.

Essential oils are volatile substances produced by plant as secondary metabolites which comprise different bioactive compounds like monoterpenoids, sesquiterpenoids, higher terpenoids etc. Essential oils have received more attention as promising insecticide as they show broad spectrum of activity against insect pest along with low mammalian toxicity and biodegradability in the environment [5]. Essential oils also show a broad spectrum of activity against different plant pathogenic fungi ranging from insecticidal, antifeedant, repellent, oviposition deterrent, and insect 
growth regulatory to antivector activities [6].

The North-East India holds eccentric position in the world map of plant diversity. Being a part of North- East India, Assam is also rich in both flora and fauna diversity. In Assam, from ancient time various aromatic plants are used for medicinal purpose along with as insects controlling agent.

Aegle marmelos (L), a tree under the Rutaceae family commonly known as "Bael", is a native plant of India with religious and medicinal importance [7]. The tree has a trunk with spiny branches and green leaves with three leaflets which release a fragrance when bruised [8]. Various parts of this tree already have been widely studied for their medicinal uses like in the treatment of heart diseases, dysentery, inflammation, diabetes, ulcer etc. [8-10]. Besides the medicinal uses, this plant was also studied for their antimicrobial, antifungal and insecticidal properties $[8,9]$. The effect of leaf extracts of Aegle marmelos was also studied against Anopheles subpictus (Grassi, 1899) in their oviposition deterrent, ovicidal and repellent activities [7]. Larvicidal activity of the essential oil of Aegle marmelos was also reported against Culex pipiens (L., 1758) and Aedes aegypti $[2,8]$.

A detailed study was also done regarding the constituents of the essential oil from leaves of Aegle marmelos. Some of such previous studies reported presence of various compounds in the essential oil like limonene, ocimene, caryophyllene, $\alpha$ - pinene etc. However no elaborate studies of this plant essential oil was found to be assayed against all the developmental stages of Aedes aegypti and Culex quinquefasciatus.

Keeping these points in mind, the present investigation aimed at studying the effect of the essential oil from the leaves of Aegle marmelos against Aedes aegypti (L) and Culex quinquefasciatus (Say). Again, GC-MS analysis was also targeted to know about the constitutive compounds of this plant essential oil grown in North Eastern Region of India.

\section{Materials and Methodology}

\subsection{Rearing of Ae. aegypti and Cx. quinquefasciatus}

The eggs of Ae. aegypti and Cx. quinquefasciatus were collected from ICMR (Indian Council of Medical Research), Dibrugarh, India. The collected eggs were reared in insect culture room, Dept. of Zoology, Gauhati University by following the rearing practices described by Arivoli et al [11].The colonies were maintained at the temperature between $25-29^{\circ} \mathrm{C}$ temperature and $80-90 \%$ relative humidity. Larvae were fed on larval food (powdered dog biscuit and yeast in the ratio 3:1) and adult mosquitoes on 10 per cent glucose solution. Pupae were transferred to a disposable cup and it is kept inside the cage. In the $4^{\text {th }}$ day after hatching, adult female mosquitoes were blood-fed on restrained albino rat for egg production.

\subsection{Collection of Plant Material}

Leaves of Aegle marmelos were collected from Nalbari district of Assam.

\subsection{Extraction of Essential Oil}

The essential oil was extracted from the plant with the help of hydro-distillation method using Clevenger apparatus.

\subsection{Mosquito Ovicidal Bioassay}

The ovicidal bioassay was performed according to the method described by Tennyson et al [12] and Puspanathan et al [13] with little modifications. For the ovicidal bioassay, 50 eggs of each species were transferred to each of the three replicates of each concentration. Eggs were exposed to the DMSO and water was treated as control. For determination of LC50 values, a wide numbers of concentrations of the oils were tested against the target species. The number of eggs hatched in control and treatments were recorded and the percentage of ovicidal activity was calculated by the following formula-

Percent ovicidal activity $=(\%$ of eggs hatched in control - $\%$ of eggs hatched in treated $/ \%$ of eggs hatched in control) $\times 100$

A total of three replicates of each experiment were carried out.

\subsection{Mosquito Larvicidal Bioassay}

Screening of the efficacy of essential oils was done by performing bioassay studies against different developmental stages of Ae. aegypti and $C x$. quinquefasciatus. The larvicidal activity of individual essential oil was assayed following the technique described earlier by Tong et al. [14] and WHO guidelines [15]. According to the WHO protocol for larvicides testing for laboratory testing, batches of 20 numbers of healthy $4^{\text {th }}$ instar larvae of each species were transferred to the disposable glasses with the depth between $5-10 \mathrm{~cm}$ having $100 \mathrm{ml}$ of water. A series of concentration from the $1000 \mathrm{ppm}$ to $10 \mathrm{ppm}$ were used to examine the larvicidal toxicity of the oil. The LC50 values are recorded after 24, 48 and 72 hour exposure. Each concentration was assayed in triplicate along with one negative control group in water and one positive control group with the DMSO. If the pupation occurred in the exposure time or more than $10 \%$ larva was died in the control group, the test was repeated. From the data, LC50 values were determined by probit analysis (SPSS 16).

\subsection{Mosquito Adulticidal Bioassay}

For the adulticidal bioassay, the impregnated filter paper bioassay method described by Ramar et al [16] was followed with some modifications. For this assay, 10 specimens of 4-5 days old non blood fed female mosquitoes were selected for 
each group. Three replicates were made for each concentration. Based on the preliminary screening, the different concentration of selected essential oil was prepared in $2 \mathrm{ml}$ of acetone and applied on Whatman no. 1 filter papers (size $12 \times 15 \mathrm{~cm}^{2}$ ), control papers were treated with $2 \mathrm{ml}$ of acetone alone and placed in exposure tubes. 3-5 days old sugar fed mosquitoes are transferred to each tube after the evaporation time of 10 minutes of acetone. The mortality was recorded up to 72 hours. The LC50 value was recorded after the values were pooled for analyses in the log dose probit analysis. If mortality exceeds $20 \%$ in the control batch, the whole test should be rejected.

\subsection{Mosquito Repellent Bioassay}

Repellent bioassay was done according to the method of Barnard et al [17]. For the study of repellent activity, the protection time was calculated taking olive oil as control. For this test, three-four days old blood-starved female mosquitoes of each species (50) were kept in a net cage ( $47 \mathrm{x}$ $35 \times 31 \mathrm{~cm} 2$ ). The dorsal side of the arms of the test person was covered with the rubber gloves except an area of $5 \mathrm{~cm}^{2}$. This area was covered with a muslin cloth. On the cloth $0.5 \mathrm{ml}$ of tested solution was applied where olive oil was used as control. After air drying the arms of the test person, the control and treated arms were introduced simultaneously into the cage. The landing of mosquitoes was observed by exposing the treated area inside the cage for 5 minutes after every 30 minutes from $11 \mathrm{AM}$ to $4 \mathrm{PM}$ for Aedes aegypti and from $8 \mathrm{PM}$ to 11PM for Culex quinquefasciatus. The experiment was conducted three times for each concentration. It was observed that there was no skin irritation from the essential oil tested. The protection time was calculated by the following formula

Protection time $=$ Time of first landing of mosquito in treated Time of first landing of mosquito in control

\subsection{GC-MS Analysis of Essential Oil}

Sample of essential oil was analyzed using Gas Chromatography (Agilent GC 7890A) and Mass spectrophotometry (Accu TOF GCv from Jeol instrument).
The programme was set as " $10: 1$; 60-1M-8-200-5M-8-275-3M-5-280-HP5-CHC13”.Three major peaks were analyzed with library (NIST) data and the probable constituent compound(s) was identified for the essential oil.

\subsection{Statistical Procedures}

The data were corrected for the mortalities with the help of Abbott correction factor and were subjected to probit analysis using SPSS software to estimate LC50 values of effective essential oil against the mosquito. Again, if mortality in the controls was found above $5 \%$, results with the treated samples were corrected using Abbott's formula [18].

\section{Result}

\subsection{Ovicidal Activity}

During the study of the ovicidal activity of the essential oil against both the target pest, no hatching of larvae were observed till 24 hours. Hatching of larvae were observed from 24 hours to 72 hours. No further hatching was recorded after 72 hour of treatment. Therefore LC50 value of ovicidal activity was recorded at 72 hour of exposure period (Table.4). At 1000 ppm concentration, $77.7 \%, 82.2 \%$ and $82.7 \%$, at 500 ppm concentration, $82 \%, 85.5 \%$ and $86.52 \%$ hatching was recorded and at $100 \mathrm{ppm}$ concentration hatching of larvae were recorded as $92.3 \%, 95.6 \%$ and $95.6 \%$ at 24 hour, 48 hour and 72 hour respectively in case of $C x$. quinquefasciatus. For Ae. aegypti, hatching percentage at $1000 \mathrm{ppm}$ concentration was recorded as $21.4 \%, 27.6 \%$ and $37.9 \%$, at $500 \mathrm{ppm}$ concentration the hatching percentage were $26.18 \%, 34.5 \%, 39.1 \%$ and at $100 \mathrm{ppm}$ concentration hatching percentage was recorded as $39.29 \%, 62.03 \%$ and $62.05 \%$ respectively at 24 hour, 48 hour and 72 hour after treatment (Table1). The LC50 value along with the regression equation is listed in table 2 . Ovicidal activity of the plant oil was found higher against Ae. aegypti than $C x$. quinquefasciatus.

Table 1. Hatching percentage of eggs of Ae. aegypti and Cx. quinquefasciatus after treatment of essential oil of Aegle marmelos

\begin{tabular}{|c|c|c|c|c|c|c|c|}
\hline \multirow{3}{*}{ No of individuals } & \multirow{2}{*}{$\begin{array}{c}\text { Concentration } \\
(\mathrm{ppm})\end{array}$} & \multicolumn{3}{|c|}{ Aedes aegypti } & \multicolumn{3}{c|}{ Culex quinquefasciatus } \\
\cline { 3 - 8 } & $\begin{array}{c}\text { 24hour } \\
\text { Average } \pm \text { SE) }\end{array}$ & $\begin{array}{c}\text { 48hour } \\
\text { (Average } \pm \text { SE) }\end{array}$ & $\begin{array}{c}\text { 72hour } \\
\text { (Average } \pm \text { SE) }\end{array}$ & $\begin{array}{c}\text { 24hour } \\
\text { (Average } \pm \text { SE) }\end{array}$ & $\begin{array}{c}\text { 48hour } \\
\text { (Average } \pm \text { SE) }\end{array}$ & $\begin{array}{c}72 \mathrm{hour} \\
\text { (Average } \pm \text { SE) }\end{array}$ \\
\hline \multirow{3}{*}{150} & 10 & $48.79 \pm 1.18$ & $79.4 \pm 2.11$ & $79.8 \pm 0.33$ & $93.08 \pm .32$ & $95.6 \pm .32$ & $96.7 \pm 0$ \\
\cline { 2 - 8 } & 100 & $39.29 \pm 0.59$ & $62.03 \pm 0.58$ & $62.05 \pm 1.11$ & $92.3 \pm .57$ & $95.6 \pm .32$ & $95.6 \pm 0.32$ \\
\cline { 2 - 8 } & 500 & $26.18 \pm 0.33$ & $34.5 \pm 0.87$ & $39.1 \pm 1.17$ & $82 \pm 1.01$ & $85.5 \pm .67$ & $86.52 \pm 0.58$ \\
\cline { 2 - 8 } & 1000 & $21.4 \pm 1.47$ & $27.6 \pm 0.59$ & $37.9 \pm 2.11$ & $77.7 \pm .87$ & $82.2 \pm 1.45$ & $82.7 \pm 0.87$ \\
\hline
\end{tabular}


Table 2. Ovicidal activity of essential oil of Aegle marmelos against Aedes aegypti and Culex quinquefasciatus

\begin{tabular}{|c|c|c|c|c|c|c|c|c|c|c|}
\hline \multirow{3}{*}{ Time } & \multicolumn{5}{|c|}{ Aedes aegypti } & \multicolumn{5}{|c|}{ Culex quinquefasciatus } \\
\hline & \multirow[b]{2}{*}{ LC50 } & \multirow[b]{2}{*}{$\begin{array}{l}\text { Regression } \\
\text { equation }\end{array}$} & \multicolumn{2}{|c|}{$95 \%$ confidence level } & \multirow[b]{2}{*}{$\begin{array}{l}\text { Chi-square } \\
\text { value }\end{array}$} & \multirow[b]{2}{*}{ LC50 } & \multirow{2}{*}{$\begin{array}{l}\text { Regression } \\
\text { equation }\end{array}$} & \multicolumn{2}{|c|}{$95 \%$ confidence level } & \multirow[b]{2}{*}{$\begin{array}{c}\text { Chi-square } \\
\text { value }\end{array}$} \\
\hline & & & $\begin{array}{l}\text { Lower } \\
\text { bound }\end{array}$ & $\begin{array}{l}\text { Upper } \\
\text { bound }\end{array}$ & & & & $\begin{array}{l}\text { Lower } \\
\text { bound }\end{array}$ & $\begin{array}{l}\text { Upper } \\
\text { bound }\end{array}$ & \\
\hline $\begin{array}{c}72 \\
\text { hour }\end{array}$ & 278.82 & $Y=3.95+0.43 x$ & .342 & .516 & 72.90 & - & - & - & - & - \\
\hline
\end{tabular}

: LC50 values could not be determined

Table 3. Survivability of larvae of Cx. quinquefasciatus and Ae. aegypti after treatment with essential oil

\begin{tabular}{|c|c|c|c|c|c|c|c|}
\hline \multirow{3}{*}{ No of individuals } & \multirow{2}{*}{$\begin{array}{c}\text { Concentration } \\
(\mathrm{ppm})\end{array}$} & \multicolumn{3}{|c|}{ Aedes aegypti } & \multicolumn{3}{c|}{ Culex quinquefasciatus } \\
\cline { 2 - 8 } & $\begin{array}{c}\text { 24hour } \\
\text { (Average } \pm \text { SE) }\end{array}$ & $\begin{array}{c}\text { 48hour } \\
(\text { Average } \pm \text { SE) }\end{array}$ & $\begin{array}{c}\text { 72hour } \\
\text { (Average } \pm \text { SE) }\end{array}$ & $\begin{array}{c}\text { 24hour } \\
\text { (Average } \pm \text { SE) }\end{array}$ & $\begin{array}{c}\text { 48hour } \\
\text { (Average } \pm \text { SE) }\end{array}$ & $\begin{array}{c}\text { 72hour } \\
\text { (Average } \pm \text { SE) }\end{array}$ \\
\hline \multirow{3}{*}{60} & 10 & $100 \pm 0$ & $100 \pm 0$ & $100 \pm 0$ & $100 \pm 0$ & $100 \pm 0$ & $100 \pm 0$ \\
\cline { 2 - 8 } & 100 & $100 \pm 0$ & $100 \pm 0$ & $100 \pm 0$ & $80 \pm 0$ & $70 \pm 0.33$ & $50 \pm 0.33$ \\
\cline { 2 - 8 } & 500 & $100 \pm 0$ & $100 \pm 0$ & $100 \pm 0$ & $20 \pm 0.33$ & $10 \pm 0.33$ & $10 \pm 0.59$ \\
\cline { 2 - 8 } & 1000 & $100 \pm 0$ & $100 \pm 0$ & $100 \pm 0$ & $0 \pm 0$ & $0 \pm 0$ & $0 \pm 0$ \\
\hline
\end{tabular}

Table 4. Larvicidal activity of essential oil of Aegle marmelos against Culex quinquefasciatus

\begin{tabular}{|c|c|c|c|c|c|}
\hline \multirow{2}{*}{ Time } & \multicolumn{5}{|c|}{ Culex quinquefasciatus } \\
\cline { 2 - 5 } & $\begin{array}{c}\text { LC50 } \\
\text { (ppm) }\end{array}$ & \multirow{2}{*}{ Regression equation } & Lower bound & Upper bound & \multirow{2}{*}{ Chi- square value } \\
\cline { 3 - 6 } & 185.69 & $\mathrm{Y}=-1.51+2.87 \mathrm{x}$ & 1.897 & 3.056 & 7.86 \\
\hline 24 hour & 167.42 & $\mathrm{y}=-0.60+2.52 \mathrm{x}$ & 1.94 & 3.08 & 9.04 \\
\hline 78 hour & 121.88 & $\mathrm{y}=-0.19+2.42 \mathrm{x}$ & 1.75 & 2.81 & 5.86 \\
\hline 72 hour & &
\end{tabular}

Table 5. Survivability of adult Cx quinquefasciatus and Ae.aegypti after treatment of essential oil

\begin{tabular}{|c|c|c|c|c|c|c|c|}
\hline \multirow{2}{*}{$\begin{array}{c}\text { No of } \\
\text { individuals }\end{array}$} & $\begin{array}{c}\text { Concentration } \\
(\mathrm{ppm})\end{array}$ & \multicolumn{3}{|c|}{ Aedes aegypti } & \multicolumn{3}{|c|}{ Culex quinquefasciatus } \\
\cline { 2 - 8 } & $\begin{array}{c}\text { 24hour } \\
\text { Average } \pm \text { SE) }\end{array}$ & $\begin{array}{c}\text { 48hour } \\
(\text { Average } \pm \text { SE) }\end{array}$ & $\begin{array}{c}\text { 72hour } \\
\text { (Average } \pm \text { SE) }\end{array}$ & $\begin{array}{c}\text { 24hour } \\
\text { (Average } \pm \text { SE) }\end{array}$ & $\begin{array}{c}\text { 48hour } \\
\text { (Average } \pm \text { SE) }\end{array}$ & $\begin{array}{c}\text { 72hour } \\
\text { (Average } \pm \text { SE) }\end{array}$ \\
\hline \multirow{3}{*}{30} & 10 & $100 \pm 0$ & $100 \pm 0$ & $100 \pm 0$ & $100 \pm 0$ & $90 \pm 0$ & $86.6 \pm 0.33$ \\
\cline { 2 - 8 } & 100 & $100 \pm 0$ & $100 \pm 0$ & $100 \pm 0$ & $83.33 \pm 0.33$ & $60 \pm 0.58$ & $56.67 \pm 0.33$ \\
\cline { 2 - 8 } & 500 & $100 \pm 0$ & $100 \pm 0$ & $100 \pm 0$ & $43.33 \pm 0.89$ & $36.67 \pm 0.58$ & $33.33 \pm 0.42$ \\
\cline { 2 - 8 } & 1000 & $100 \pm 0$ & $100 \pm 0$ & $100 \pm 0$ & $0 \pm 0$ & $0 \pm 0$ & $0 \pm 0$ \\
\hline
\end{tabular}

Table 6. Adulticidal activity of essential oil of Aegle marmelos against $\mathrm{Cx}$. quinquefasciatus

\begin{tabular}{|c|c|c|c|c|c|}
\hline \multirow{2}{*}{ Time } & \multirow{2}{*}{$\begin{array}{c}\text { LC50 } \\
(\mathrm{ppm})\end{array}$} & \multirow{2}{*}{ Regression equation } & \multicolumn{2}{|c|}{$95 \%$ confidence level } & \multirow{2}{*}{ Chi- square value } \\
\cline { 4 - 5 } & 288.56 & $\mathrm{Y}=-1.97+2.83 \mathrm{x}$ & 2.274 & 3.681 & 16.22 \\
\hline 24 hour & 164.67 & $\mathrm{y}=1.70+1.49 \mathrm{x}$ & 1.10 & 1.87 & 19.89 \\
\hline 78 hour & 121.50 & $\mathrm{y}=1.99+1.45 \mathrm{x}$ & 1.09 & 1.80 & 19.17 \\
\hline 72 hour & &
\end{tabular}

\subsection{Larvicidal Activity}

During the study of larvicidal activity of essential oil of Aegle marmelos, different concentrations of the oil was prepared and tested against Ae. aegypti and $C x$. quinquefasciatus. In the study it was found that the larval mortality was directly related to the exposure time and concentration of the oil (Table 3). As larvicides, the oil of Aegle marmelos showed more effect against Culex quinquefasciatus than Aedes aegypti. For $C x$. quinquefasciatus the LC50 values of the oil at $24 \mathrm{~h}, 48 \mathrm{~h}$ and $72 \mathrm{~h}$ was recorded as $185.69 \mathrm{ppm}, 167.42 \mathrm{ppm}$ and $121.88 \mathrm{ppm}$ respectively while for Ae. aegypti no larvicidal effect was observed. The values of sub lethal concentrations are presented along with the regression equations, 95\% confidence level in table-4.

\subsection{Adulticidal Activity}

No adulticidal effect of the plant oil against Ae. aegypti species was recorded till 72 hours after treatment with 100 to $1000 \mathrm{pppm}$ concentration. But in case of $C x$. quinquefasciatus, adults were more susceptible to this oil as it showed LC50 value $288.56 \mathrm{ppm}, 164.67 \mathrm{ppm}$ and $121.50 \mathrm{ppm}$ respectively at 24 hours, 48 hours and 72 hours (Table-6).The survivability of adults after 24 hour, 48hour and 72 hour of treatment is presented in table -5 


\subsection{Protection Time}

Table 7. Protection time of essential oil of Aegle marmelos against Ae. Aegypti and Cx. quinquefasciatus

\begin{tabular}{|c|c|c|}
\hline Species & Control (Olive oil) & Oil (Aegle marmelos) \\
\hline Aedes aegypti & 5 minutes & 1 hour \\
\hline $\begin{array}{c}\text { Culex } \\
\text { quinquefasciatus }\end{array}$ & 5 minutes & 5 minutes \\
\hline
\end{tabular}

The result of the repellent effect of the essential oil was assessed in terms of determining the protection time. In the repellent study of this essential oil, commercially available olive oil was used as control. The result showed comparatively better protection time of the plant oil against Ae aegypti (1 hour) in comparison to Cx quinquefasciatus (5 min). In both larvicidal and repellent activities, this essential oil showed higher efficacy against Ae.aegypti than Cx.quinquefasciatus (table-7).

\subsection{GC-MS Analysis}

After extraction of the essential oils from the fresh leaves of Aegle marmelos, to identify different constituent compounds, GC-MS analysis was carried out. The identity, retention time, area and percentage composition of the essential oil of Aegle marmelos are presented in the table-8. The GC-MS report showed $\beta$ - terpinyl acetate, 5isopropenyl-2- methyl-7-oxabicyclo(4.1.0) hepten-2-oland 2,3-pinanediol as probable major constituent of the particular oil (Table 8, fig-1)

Table 8. Different components of essential oil from leaves of Aegle marmelos obtained from GC- MS analysis

\begin{tabular}{|c|c|c|c|c|c|}
\hline Component & Area $(\%)$ & $\begin{array}{c}\text { Molecular } \\
\text { weight }\end{array}$ & Retention index & $\begin{array}{l}\text { Chemical } \\
\text { formula }\end{array}$ & Retention time \\
\hline$\alpha$-pinene & & 136 & 922 & $\mathrm{C}_{10} \mathrm{H}_{16}$ & 4.43 \\
\hline$\beta$-myrcene & & 136 & 979 & $\mathrm{C}_{10} \mathrm{H}_{16}$ & 5.36 \\
\hline Bicyclo(3.1.0)hexane, 4-methyl-1-(1-methylethyl & & 136 & 873 & $\mathrm{C}_{10} \mathrm{H}_{16}$ & 5.64 \\
\hline$\beta$ - terpinyl acetate & 25.82 & 196 & 1267.2 & $\mathrm{C}_{12} \mathrm{H}_{20} \mathrm{O}_{2}$ & 6.1 \\
\hline$\beta$-linalool & & 154 & 1082 & $\mathrm{C}_{10} \mathrm{H}_{18} \mathrm{O}$ & 7 \\
\hline 2-cyclohexen-1-ol, 1-methyl-4-(1-methylethyl) & & 154 & 1109 & $\mathrm{C}_{10} \mathrm{H}_{18} \mathrm{O}$ & 7.87 \\
\hline Cis-verbenol & & 152 & 1127 & $\mathrm{C}_{10} \mathrm{H}_{16} \mathrm{O}$ & 8.31 \\
\hline crypton & 8.14 & 138 & 1069 & $\mathrm{C}_{9} \mathrm{H}_{14} \mathrm{O}$ & 9.06 \\
\hline Cis- sabinol & 1.64 & 152 & 1085 & $\mathrm{C}_{10} \mathrm{H}_{16} \mathrm{O}$ & 9.43 \\
\hline Cis- carveol & 1.78 & 152 & 1206 & $\mathrm{C}_{10} \mathrm{H}_{16} \mathrm{O}$ & 9.73 \\
\hline 5- isopropenyl-2- methyl-7-oxabicyclo(4.1.0) hepten-2-ol & 11.95 & 168 & 1169 & $\mathrm{C}_{10} \mathrm{H}_{16} \mathrm{O}_{2}$ & 10.19 \\
\hline 3- tetradecyn-1-ol & & 210 & 1673 & $\mathrm{C}_{14} \mathrm{H}_{26} \mathrm{O}$ & 10.43 \\
\hline camphenol & 7.32 & 152 & 1082 & $\mathrm{C}_{10} \mathrm{H}_{16} \mathrm{O}$ & 11.06 \\
\hline 2,3-pinanediol & & 170 & 1276 & $\mathrm{C}_{10} \mathrm{H}_{18} \mathrm{O}_{2}$ & 11.47 \\
\hline 5- isopropenyl-2-methyl-7-oxabicyclo(4.1.0) heptan-2-ol & 13.69 & 168 & 1169 & $\mathrm{C}_{10} \mathrm{H}_{16} \mathrm{O}_{2}$ & 11.71 \\
\hline Dipentene oxide & & 168 & 1128 & $\mathrm{C}_{10} \mathrm{H}_{16} \mathrm{O}_{2}$ & 12.34 \\
\hline 2,3-pinanediol & 9.70 & 170 & 1276 & $\mathrm{C}_{10} \mathrm{H}_{18} \mathrm{O}_{2}$ & 13.05 \\
\hline Piperitone oxide & & 168 & 1171 & $\mathrm{C}_{10} \mathrm{H}_{16} \mathrm{O}_{2}$ & 13.37 \\
\hline Trans-3(10)-caren-2-ol & 8.71 & 152 & 1131 & $\mathrm{C}_{10} \mathrm{H}_{16} \mathrm{O}$ & 13.79 \\
\hline $\begin{array}{c}\text { Bicyclo-(3.1.0) } \\
\text { hexane-6-methanol,2-hydroxy-1.4.4-trimethyl }\end{array}$ & 3.90 & 170 & 1322 & $\mathrm{C}_{10} \mathrm{H}_{18} \mathrm{O}_{2}$ & 14.59 \\
\hline Caryophyllene oxide & 4.63 & 220 & 1507 & $\mathrm{C}_{15} \mathrm{H}_{24} \mathrm{O}$ & 15.69 \\
\hline 12-oxabicyclo $(9,1,0)$ dodeca-3,7-diene $1,5,5,8$ - tetramethyl & & 220 & 1592 & $\mathrm{C}_{15} \mathrm{H}_{24} \mathrm{O}$ & 16.09 \\
\hline
\end{tabular}




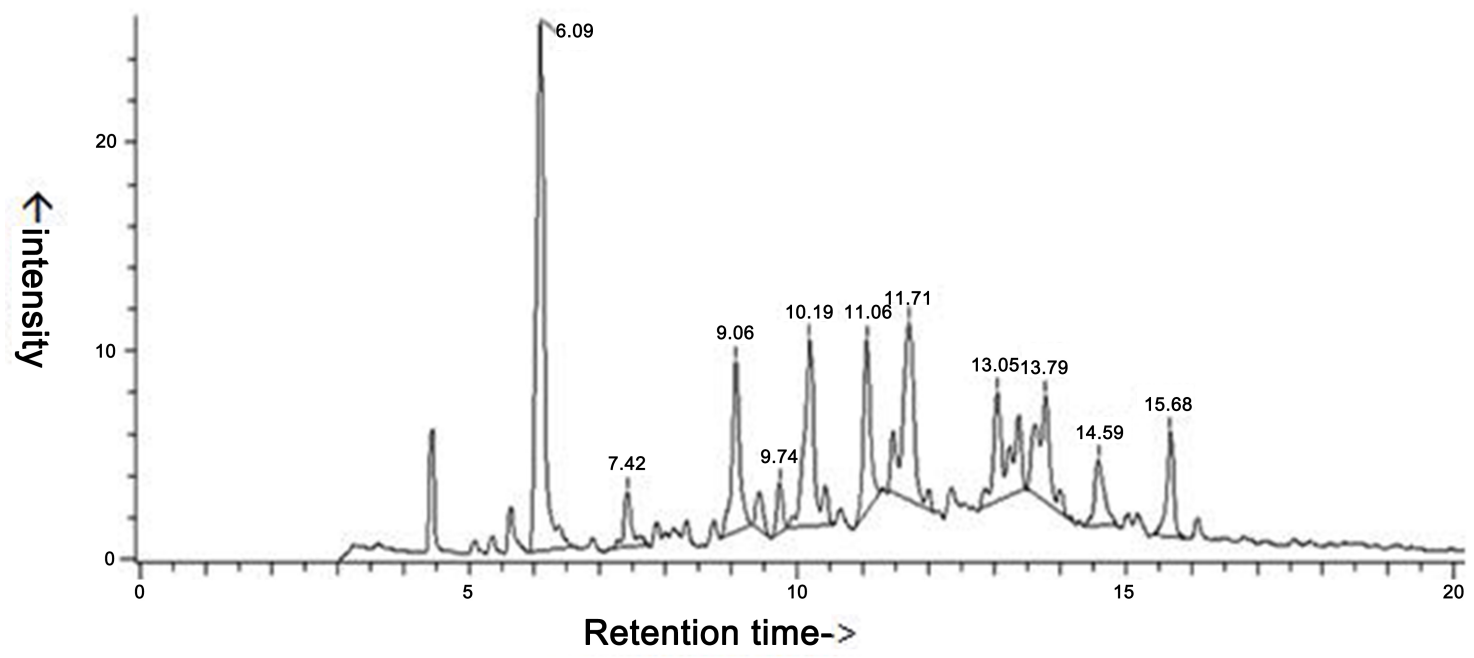

Figure 1. Chromatogram of GC-MS analysis of essential oil of the leaves of Aegle marmelos

\section{Discussion}

In the present study, the essential oil from the leaves of Aegle marmelos exhibited insecticidal activities against different developmental stages of the two target species, Ae. aegypti and $C x$. quinquefasciatus. The findings revealed variation in the potentiality of the essential oil in different development stages of the two mosquito species.

In case of $C x$. quinquefasciatus, the oil showed highest larvicidal activity (LC50 value $=121.88 \mathrm{ppm}$ at 72 hour) followed by the adulticidal activity (LC50 value $=121.50 \mathrm{ppm}$ at 72 hour) but no repellent and ovicidal activities was observed. Bioassay against Ae. aegypti reported highest ovicidal (LC50 value $=278.82 \mathrm{ppm}$ at 72 hour) and repellent effect (Protection time $=1$ hour). As larvicidal and adulticidal agent, the essential oil showed no potent effect against $A e$. aegypti. Thus the same essential oil showed completely different activity response against the two mosquito species though they belong to the same family "Culicidae".

In the present study the larval stage of $C x$. quinquefasciatus was recorded as more susceptible among all the developmental stages. This is in conformity with the findings of Fox et al. [19] where they suggested larvae as more responsive to any physical as well as chemical stresses than other developmental stages. The egg stage was found less susceptible among all developmental stages. Like other insects, eggs of mosquitoes are also covered with shell which differs significantly from the integument of the larva in their structure and biochemical constituents which may add difference in the penetration rate of different insecticides to the body [20]. In contrast, bioassay against Ae. aegypti revealed that the egg stage is more susceptible among all the developmental stages. Variations in some factors like chitin content of the egg shell, egg volume ratio and egg surface density influence the levels of egg resistance to any stress [21] and these factors vary in different species.

Screening of effective essential oil as repellent is highly valuable for making safe protection from the bite of blood-sucking mosquitoes. The desired qualities in the design of a repellent mainly include long protection time, low toxicity to humans, and non-irritating to skin [2]. Current study of determining the protection time of the essential oil from the leaves of Aegle marmelos against the two target species showed one hour protection time against Ae. aegypti while no repellent activity was found against $C x$. quinquefasciatus. According to previous research, the repellent effect of any essential oil against mosquitoes showed variation due to some factors like temperature, wind, humidity, presence of different phytochemicals etc. [22, 23]. Again, the age of mosquitoes, body size and density in the cage are also responsible for such outcomes [17].

One of the important factors responsible for the insecticidal effect is the major compounds present in the essential oil including its quality and quantity [24]. The compounds including alcohols, aldehydes, fatty acid derivatives, terpenoids, and phenolics may jointly or independently contribute to insecticidal, repellent as well as antifeeding activities [25]. The toxicity of essential oil may be attributed to their major constituents [26]. Report of GC-MS analysis of Aegle marmelos oil in the current study showed $\beta$ - terpinyl acetate, 5- isopropenyl-2methyl-7-oxabicyclo (4.1.0) hepten-2-ol and 2, 3-pinanediol as propable major compounds. This result is highly differing from lots of previous studies conducted in other parts of India which implied limonene as the major compound $[8,9$, 27, 28]. Additional study on the same essential oil in other parts of India reported presence of phellandrene, myrcene and eucalyptol as major compound. Again, study on the same essential oil in Egypt by Ibrahim et al. (2015) reported $\gamma$ cadinene as major compound. Geographic locations, climatic condition, method of extraction, time of harvesting are some of the factors which influence those variations of the profile of constituents of an essential oil [29-30].

Therefore, essential oil of A. marmelos which is inexpensive, easily available at farm level, environmentally safe with low mammalian toxicity can be recommended as a 
good alternative to synthetic insecticides against the mosquitoes.

\section{Conclusions}

The findings of present investigation emphasized the efficacy of Aegle marmelos as potent ovicide against Aedes aegypti and potent larvicide and adulticide against $C x$ quinquefasciatus. But further studies regarding the mode of action and field application are necessary to provide a futuristic lead product from Aegle marmelos for mosquito control.

\section{Acknowledgements}

The authors are very much thankful to the UGC and DST for their financial help and SAIF, IIT, BOMBAY for their valuable help in the present investigation

\section{REFERENCES}

[1] A.D. Reegan, M.R. Gandhi, M. G. Paulraj, S. Ignacimuthu, Ovicidal and Oviposition Deterrent Activities of Medicinal Plant Extracts against Aedes aegypti L. and Culex quinquefasciatus Say Mosquitoes (Diptera: Culicidae), Osong Public Health Res Prospect. Vol.6, No.1, 64-69, 2014.

[2] A. Vineetha, K. Murugan, Larvicidal and smoke repellency effect of Toddalia asiatica and Aegle marmelos against the dengue vector, Aedes aegypti (Insecta: Diptera: Culicidae), Entomological Research. Vol. 39, 61-65, 2009.

[3] S.K. Hendarto, S.R. Hadinegoro, Dengue encephalopathy, Acta Paediatr Jap. Vol. 34, No. 3, 350-357, 1992.

[4] C. Pancharoen, W. Kulwichit, T. Tantawichien, Dengue infection: a global concern, J Med Assoc Thai. Vol. 85, 25-33, 2002.

[5] M.Tiwary, S.N. Naika, K. Tiwary, P.K. Mittal, Chemical composition and larvicidal activities of the essential oil of Zanthoxylum armatum DC (Rutaceae) against three mosquito vectors, J. Vect Borne Dis.Vol.44, 198-204, 2007.

[6] O. Koul, S. Walia, G. S. Dhaliwal, Essential Oils as Green Pesticides: Potential and Constraints, Biopestic. Int. Vol. 4, No. 1, 63-84, 2008.

[7] G. A. A.Elango, Rahuman, A. Bagavan, C. Kamaraj, A. A Zahir, C. Venkatesan, Laboratory study on larvicidal activity of indigenous plant extracts against Anopheles subpictus and Culex tritaeniorhynchus, Parasitology Research, Vol. 104, 1381-1339, 2009.

[8] P.Satyal, K. E. Woods, N. S. Dosoky, S. Neupane, W. N. Setzer, Biological activities and volatile constituents of Aegle marmelos (L.)Correa from Nepal, Journal of Medicinally Active Plants, Vol.1, No. 3, 114-122, 2012.

[9] R., A. Kumar, C. S. Prasal, N. K. Dubey, R. Samant,
Insecticidal activity Aegle marmelos (L.) Correa essential oil against four stored grain insect pests, International Journal of Food Safety, 39-49, 2008

[10] N. A. Ibrahim, F. S. El-Sakhawy, M. M. D. Mohammad, M. A. Farid, N. A. M. Abdel-Wahed, D. A. H. Deabes, Chemical composition, antimicrobial and antifungal activities of essential oils of the leaves of Aegle marmelos(L.) Correa growing in Egypt, Journal of Applied Pharmaceutical Science, 2015.Vol. 5, No. 02, 001-005, 2015.

[11] S. Arivoli, S. Tennyson, Larvicidal and adult emergence inhibition activity of Abutilon indicum (Linn.) (Malvaceae) leaf extracts against vector mosquitoes (Diptera: Culicidae), Journal of Biopesticides, Vol.4, No.1, 27 - 35, 2011.

[12] S.Tennyson, K. J. Ravindran,S. Arivoli,Screening of plant extracts for ovicidal activity against Culex quinquefasciatus Say( Diptera: Culicidae), Applied Botany, Vol. 40, 5456-5460, 2011

[13] T. A. Pushpanathan, M. Govindarajan, Larvicidal, ovicidal and repellent activities of Cymbopogan citratus Stapf (Graminae) essential oil against the filarial mosquito Culex quinquefasciatus (Say) (Diptera :Culicidae), Tropical Biomedicine, Vol. 23, No.2, 208-212, 2006.

[14] F.Tong, J.R. Bloomquist, Plant Essential Oils Affect the Toxicities of Carbaryl and Permethrin against Aedes aegypti (Diptera: Culicidae), Journal of Medical Entomology, Vol. 50, N0. 4, 826-832, 2013

[15] WHO guidelines for laboratory and field testing of mosquito larvicides. 2005. 13.

[16] M. Ramar, Ignacimuthu, G.M. Paulraj, Biological activity of nine plant essential oils on the filarial vector mosquito, Culex quinquefasciatus Say. (Insect: Diptera: Culicidae), International journal of research in biological science, Vol. 4, No. 1, 1-5, 2013.

[17] D. Barnard, K.H. Posey, D. Smith, C.E. Schreck, Mosquito density, biting rate and cage size effects on repellent tests, Med. Vet. Entomol, Vol.12, 39-45, 1998.

[18] W. S. Abbott, A method of computing the effectiveness of an insecticide, Journal of the American Mosquito control association; Vol. 3, No. 2, 1925.

[19] C. W. Fox, D.A. Roff, D.J. Fairbairn, Evolutionary ecology: Concepts and Case Studies, Oxford University Press.2001.

[20] M. Soonwera, Efficacy of essential oils from Citrus plants against mosquito vectors Aedes aegypti (Linn.) and Culex quinquefasciatus (Say). Journal of Agricultural Technology, Vol. 11, No. 3, 669-681, 2015.

[21] L. C. Farnesi, R. F. S. Menna- Barreto, A.J. Martins, D. Valle, G.L. Rezende, Physical features and chitin content of eggs from the mosquito vectors Aedes aegypti, Anopheles aqualis and Culex quinquefasciatus: Connection with distinct levels of resistance to desiccation, Journal of insect physiology, Vol. 83, $43-52,2015$.

[22] A.Uniyal, S.N. Tikar, R. Singh, S.V. Shukla, O.P. Agarwal, V.Veer, D. Sukumaran, Repellent effect, knockdown study and electrophysiological response of essential oils against Aedes aegypti, Journal of Entomology and Zoological Studies, Vol. 2, No. 5, 351-357, 2014.

[23] A. Tawatsin, P. Asavadachanukorn, U. Thavara, P. 
Wongsinkongman, J. Bansidhi, T. Boonruad, Repellency of essential oils extracted from plants in Thailand against four mosquito vectors (Diptera: Culicidae) and oviposition deterrent effects against Aedes aegypti (Diptera: Culicidae), South East Asian J. Trop. Med .Public Health, Vol. 37, No.57, 915-931, 2006

[24] N.Sutthanont, W. Choochote , B. Tuetun, A. Junkum, A. Jitpakdi, U. Chaithong, D. Royong, B. Pitasawat, Chemical composition and larvicidal activity of edible plant-derived essential oils against pyrethroid-susceptible and-resistant strains of Aedes aegypti (Diptera: Culicidae), Journal of Vector Ecology, Vol.35, N0. 1, 106-115, 2010.

[25] I. K. Park, S.C. Shin, Fumigant activity of plant essential oils and components from garlic (Allium sativum) and clove bud( Eugenia caryophyllata) oils against the Japanese termite (Reticulitermes speratus Kolbe), J. Agric. Food Chem., Vol-53, 4388-4392, 2005.

[26] R.M.Gleiser, J. A. Zygadlo, Insecticidal properties of essential oils from Lippia turbinata and Lippia polystachya (Verbenaceae) against Culex quinquefasciatus (Diptera:
Culicidae), Parasitology Research, Vol. 101, 1349-1354, 2007.

[27] H.P. Kaur, S.N. Garg, K.V. Sashidhara, A. Yadav, A.A. Naqvi, S.P.S. Khanuja, Chemical composition of the essential oil of the twig and leaves of Aegle marmelos (L.) Correa. J. Essent. Oil Res. Vol. 18, 288-289, 2006.

[28] S.N. Garg, H.P. Kaur, A.A. Naqvi, S.K. Singh, S.P.S. Khanuja Chemical examination of Aegle marmelos leaf essential oil, a potential source of limonene, Indian Perfumer, Vol. 50, 75-77, 2006.

[29] O.Ngassapa, D.K.B. Runtoro, E. Harvala, L.B. Chinou, Composotion and antimicrobial activity of essential oils of two populations of Tanzanian Lippia javanica (Burm.f.) Spreng. (Verbenaceae), Flavour and Fragrance Journal, Vol. 18, 221-224, 2003

[30] S.U. Din, W. Akram, H.A.A. Khan, A. Hussain, F. Hafeez, Citrus waste-derived essential oils: alternative larvicides for dengue fever mosquito, Aedes albopictus (Skuse) (Culicidae: Diptera), Pakistan J Zool., Vol.43, No.2, 367-372, 2011. 